\author{
REVIEW OF EUROPEAN AND COMPARATIVE LAW \\ VOLUME XXXII \\ YEAR 2018
}

\title{
THE CONSEQUENCES OF VIOLATING THE IMMUNITY OF CARTHAGINIAN ENVOYS IN THE LIGHT OF LIV. 38.42.7 AND VAL. MAX. 6.6.3
}

Izabela Leraczyk*

\begin{abstract}
The article analyses the casus of beating Carthaginian envoys in $188 \mathrm{BC}$ and the effects that this act exerted on the grounds of international law, sacral norms and, at a later time, on the grounds of criminal regulations laid by the Romans. Those issues are analyzed on the basis of the account by Titus Livius (38.42.7) and Valerius Maximus (6.6.3). The analysis demonstrates that emissaries dispatched to other peoples were protected by immunity and it also indicates the way in which envoys were chosen in the republican Rome, as well as the customs related to their reception. It is also presented in the article what types of behaviour might have been perceived as violations of envoys' immunity and what sanctions were faced by those perpetrating such acts. On the grounds of ius gentium there was a threat of declaring war, which could be averted only if the perpetrator was delivered to the affected community. On the grounds of sacral law, it was assumed that a deed of that nature entailed sacrilegium, and a blame could not be in any way removed from an individual. However, the whole society could be remitted their guilt by delivering the wrongdoer to the injured party. Further, the text analyzes the proceedings in the case of causing bodily harm to Punic envoys - the actions undertaken by the urban praetor and the procedure of delivering the perpetrators (deditio) to Carthaginians, carried out by the fetiales.
\end{abstract}

${ }^{1}$ The article is a result of a research project registered by the number 2016/21/B/ HS5/01843, financed with a grant from the National Science Centre.

* PhD - Associate Professor, Department of Roman Law, Faculty of Law, Canon Law and Administration, The John Paul II Catholic University of Lublin. 
Key words: violation of bodily integrity of an ambassador, immunity, sacrosanctus, sacrilegium, iusta causa belli, beating, Livy, Valerius Maximus

\section{INTRODUCTION}

The aim of the article is to analyze the situation in which after the occurrence of premises for declaring war, an internal control mechanism came into force in order to prevent an outbreak of a large-scale conflict. The framework for the current analysis comes from the fragments of Livy's Ab urbe condita and Valerius Maximus's Facta et dicta memorabilia, which give an account of Carthaginian envoys sustaining bodily harm in $188 \mathrm{BC}$ and Roman action with regard to the perpetrators of that deed. This event is also referred to by Cassius Dio in fragment 61, book 19 of his Roman History. In order to understand the whole casus described by the historians, in the first part of the article iusta causa belli and its significance are also briefly explained. It is followed by an analysis clarifying the status of foreign envoys and the ways in which their immunity could be violated. Finally, it is pointed out what actions had to be undertaken in order to prevent Carthage from declaring war.

With regard to the times of the Republic, multiple theories have emerged on the subject of the regulations implemented by the Romans in their relations with other states. There are some doubts concerning the very basic issues. For instance, it appears to be problematic to define whether the regulations in question were part of an integral and structured system, and to what extent the need to abide by those regulations was ingrained in the civil consciousness ${ }^{2}$. Without a doubt, it was the merit of the Romans that they developed the concept of the bellum iustum ${ }^{3}$. According to the

${ }^{2}$ Christian Baldus, Vestigia pacis. The Roman Peace Treaty: Structure or Event?, In: Peace Treaties and International Law in European History. From the Late Middle Ages to World War One, ed. Randall Lesaffer, Cambridge: Cambridge University Press 2004, 103-146.

${ }^{3}$ According to the Romans, a just war is one that is declared in accordance with sacral and legal procedure, which is laid out in the positive law. Karl Heinz Ziegler, Das Völkerrecht der römischen Republik, In: Aufstieg und Niedergang der römischen Welt, 
Romans, in order to deem a war as morally justifiable, several conditions had to be met. First of all, there had to be a justifiable reason for war (iusta causa belli) $)^{4}$, and the war itself had to be declared in accordance with specific rules ${ }^{5}$.

The most common causes for declaring a just war in the times of republican Rome were the following: breaking of international treaties, betrayal of allies or causing them harm, violation of another state's territory, but also violation of bodily integrity of envoys or refusal to surrender perpetrators of acts deemed as harmful to the other side 6 .

vol. I $I_{2}$ Von den Anfängen Roms bis zum Ausgang der Republik, ed. Joseph Vogt, Berlin-New York: De Gruyter 1972, 102. One of the effects of the procedure was to assure society of the justness of the undertaken military actions. Nadine Grotkamp, Völkerrecht im Prinzipat. Möglichkeit und Verbreitung, Frankfurt am Main: Nomos 2009, 122. The waged war should also be in line with the will of the gods (bellum pium). Marta Sordi, "Bellum iustum ac pium", In: Guerra e diritto nel mondo greco e romano, ed. Marta Sordi, Milano: Vita e Pensiero, Pubblicazioni dell'Universita Cattolica 2002, 3-11. The ethical aspect of waging war came into play as late as the $1^{\text {st }}$ century $B C$ thanks to Cicero. Werner Dahlheim, Struktur und Entwicklung des römischen Völkerrechts im 3. und 2. Jh v. Chr., München: Beck 1968, 179-180. Cf: Stephen P. Oakley, A Commentary on Livy, Books VI-X, t. III: Book IX, Oxford: Oxford University Press 2005, 47. On the concept of the bellum iustum see also: Sigrid Albert, Bellum iustum: die Theorie des "gerechten Krieges" und ihre Bedeutung für die auswärten Auseinandersetzungen Roms in republikanischer Zeit, Kallmünz: Lassleben 1980; 45-72; Mauro Mantovani, Bellum iustum. Die Idee des gerechten Krieges in der römischen Kaiserzeit, New York: Peter Lang International Academic Publishers 1990; Luigi Loreto, Il bellum iustum e i suoi equivoci: Cicerone ed una componente della rappresentazione romana del Völkerrecht antico, Naples: Jovene 2001; Alexander Yakobson, Public Opinion, Foreign Policy and 'Just War' in the Late Republic, In: Diplomats and Diplomacy in the Roman World, ed. Claude Eilers, Leiden: Brill 2009.

${ }^{4}$ Herbert Hausmaninger, "Bellum iustum und iusta causa belli im älteren römischen Recht”, Österreichische Zeitschrift für öffentliches Recht 11 (1961), 335-345.

${ }^{5}$ David J. Bederman, International Law in Antiquity, Cambridge: Cambridge University Press 2001, 223.

${ }^{6}$ Coleman Phillipson, The International Law and Custom of Ancient Greece and Rome, vol. 2, London: MacMillan 1911, 182-192. 


\section{THE CASUS OF LUCIUS MINUCIUS MYRTILUS \\ AND LUCIUS MANLIUS}

Analyzing the cases of violating bodily integrity of the envoys, one must take into account a fragment from Livy's $A b$ urbe condita:

Liv. 38.42.7: Eo anno L. Minucius Myrtilus et L. Manlius, quod legatos Carthaginienses pulsasse dicebantur, iussu M. Claudii praetoris urbani per fetiales traditi sunt legatis et Carthaginem avecti.

In that year Lucius Minucius Myrtilus and Lucius Manlius, because they were to have beaten Carthaginian envoys, by order of Marcus Claudius, the city praetor, were delivered by the fetials to envoys and taken to Carthage ${ }^{7}$.

The historian described here the events which occurred circa 188 BC, when two Roman citizens allegedly beat Carthaginian envoys who were staying in the city at that time. The event was also reported by Valerius Maximus, who described it in some greater detail:

Val. 6.6.3: Adversus eosdem hostes parem fidem in iure legationis tuendo patres conscripti exhibuere: M. enim Aemilio Lepido, L. Flaminio consulibus L. Minucium et L. Manlium Karthaginiensium legatis, quia manus his attulerant, per fetiales <a M.> Claudio praetore dedendos curaverunt. se tunc senatus, non eos, quibus hoc praestabatur, aspexit.

The Conscript Fathers showed equal faith in protecting ambassadorial rights in relation to the same enemies. In the Consulship of M. Aemilius Lepidus and L. Flaminius they had L. Minucius and L. Manlius surrendered by Praetor M. Claudius through Fetials to Carthaginian envoys because they had used violence against the same. The senate on that occasion looked at itself, not at those to whom it was making this amend ${ }^{8}$.

\footnotetext{
7 Transl. LOEB.

${ }^{8}$ Transl. LOEB.
} 
The adversely affected Carthaginians arrived in Rome as official envoys. Valerius Maximus wrote about them as of enemies ${ }^{9}$, however, formally, there was no state of war between Rome and Carthage at that time. Since 201 BC both sides had been bound by a peace treaty, which came to be broken only in $146 \mathrm{~B}$, providing a pretext for launching the third Punic $\operatorname{War}^{10}$.

None of the historians considered it worthwhile to expand their reports with details regarding Lucius Minucius Myrtilus and Lucius Manlius, hence neither their social position nor their motivation which instigated their behavior is known ${ }^{11}$. A slightly different version of the event from those provided by Livy and Valerius Maximus can be found in Cassius Dio's text, who claims that the young Romans launched only verbal abuse at the Carthaginian envoys and that after they were handed over to the Carthaginians, the latter returned the perpetrators home ${ }^{12}$.

\section{THE STATUS OF DIPLOMATIC ENVOYS}

According to historical sources, in the antique world, it was generally accepted that envoys of other states were protected and their safety was guaranteed. Official representatives of other countries enjoyed a special status, which facilitated their safe travel during their diplomatic missions.

${ }^{9}$ The term hostis was in ancient times used for describing a foreigner, whereas with regard to enemies with whom Rome was in the state of war the terms perdvellis, perduellis were used. Cic. de off. 1.12.37; Varr. De ling. Lat. 5.1.3. Maurizio Betting, Alberto Borghini, La guerra e lo scambio: hostis, perduellis, inimicus, In: Linguistica e antropologia. Atti del XIV Congresso Internazionale, Lecce 23-25 maggio 1980, Roma: Bulzoni 1983, 305312. The concept of hostis as an enemy appears in the literary sources in the $2^{\text {nd }}$ half of the $3^{\text {rd }}$ century BC. More on the subject: Francesco Sini, Bellum Nefandum. Virgilio e il problema del „diritto internazionale antico”, Sassari: Libreria Dessì Editrice 1991, 146-152.

${ }^{10}$ Liv. 30.37; Pol. 15.18. Dexter Hoyos, Mastering the West: Rome and Carthage at War, Oxford: Oxford University Press 2015, 229.

${ }^{11}$ In his Periochae Livy mentions the case of handing over the perpetrators of beating foreign ambassadors to the community of Apollonium, describing the Romans as young people (iuvenes). Liv. Per. 15.2.

${ }^{12}$ Cass. Dio. 19.61. 
As envoys of their leaders and peoples, their enjoyed specific privileges and immunities on the territory of the receiving country, also at a time when the relations between the states were hostile ${ }^{13}$. In the times of the republic, when de facto the rule was a state of war, not of peace, also the Romans abided by this law. The refusal to receive envoys was treated as behavior against the ius gentium ${ }^{14}$.

The genesis of such regulations might be found in the times when legal norms were closely intertwined with sacral norms. During the regal period and in the early republican Rome, it was the group of fetiales ${ }^{15}$ who represented Romans in contacts with other nations. It was a college of priest who stood on guard of respecting international treaties and who ensured that the procedure for declaring a just war (bellum iustum $)^{16}$ was conducted appropriately. Their duties also included the ratification of peace treaties (foedus $)^{17}$, as well as extradition. When it was necessary to send an ambas-

${ }^{13}$ David J. Bederman, International Law, 115.

${ }^{14}$ Liv. 21.10. In accordance with the ius gentium, there was a duty to accept ambassadors, whereas dispatching them was a right. In specific situations, the Roman Senate could refuse to receive and hear the envoys. An example of such behaviour is the refusal to receive the Carthaginian ambassadors at the time when Punic armies were stationary in Italy. Coleman Phillipson, The International Law, vol. 1, 311.

15 The custom of sending priests on diplomatic missions was not a Roman invention. Examples of such practices among other nations such as the Latins or Etruscans are mentioned, for instance by Titus Livius. Liv. 1.24.8-9. Also epigraphical sources provide proof that such practices were observed by other peoples. CIL 6.1302; cf. Liv. 1.32.5. On the other hand, Polybius mentioned the Carthaginians swearing onto their domestic gods. Pol. 3.25-5-9. All the above examples allow for the conclusion that also the ceremonies with regard to appointing diplomatic missions had common roots, reaching far beyond the customs observed on the Apennine Peninsula.

${ }^{16}$ Fundamental sources on the subject of the fetiales include fragments by: Liv. 1.24 ND 1.32; and also Dion. Hal. 2.72

${ }^{17}$ Declarations made by the ambassador were treated as an official stance of his state. All the declarations were strengthened by taking a solemn oath, whose breach would bring upon the perjurer the punishment sent by the gods. John Scheid, "Oral Tradition and Written Tradition in the Formation of Sacred Law in Rome", in: Religion and Law in Classical and Christian Rome, ed. Clifford Audo, Jörg Rüpke, Stuttgart: Franz Steiner Verlag 2006, 22. The fetial who was chosen to represent Rome was called pater patratus. More on the subject: Guido Fusinato, Dei feziali e del diritto feziale. Contributo alla storia del diritto pubblico esterno di Roma, In: Reale Accademia dei Lincei. Memorie della Classe di scienze morali, storiche e filologiche, XIII, Roma: Salviucci 1884. 
sador outside the borders of the state, the senate, and during earlier times a king, would appoint a member of the college of the fetiales to see to the task. It all happened in accordance with strictly laid out sacral rituals. During the ceremony, the priest with the function of fetialis verbenarius wrapped the head of a priest selected for envoyship in order to represent Rome with straps of wool and put on his head a wreath made of the turf growing on the Capitol (sagmina, verbena) ${ }^{18}$. Only a person who had been indicated by appropriate authorities and who had the permission to make declarations of will on behalf of their peoples was entitled to immunity. It is pointed out by Livy in his description of king Tullus Hostilius appointing envoys for negotiating an agreement with the Albans: Rex, facisne me tu regium nuntium populi Romani Quiritium, vasa comitesque meos? ${ }^{21}$. The protection extended over the whole entourage embarking on an ambassadorial mission (comites), including advisors or other fetiales who might be accompanying the envoy. The immunity also included the equipment (vasa), which was used during official duties, that is all sorts of objects of daily use which were indispensable during the journey.

A visible sign of the fact that the Romans were protected by immunity was a wreath made of grass and leaves (sagmina). A jurist Marcialis living in the $1^{\text {st }}$ century $\mathrm{AD}$ pointed out the following:

D. 1.8.8.1: Sanctum autem dictum est a sagminibus: sunt autem sagmina quaedam herbae, quas legati populi romani ferre solent, ne quis eos violaret [...].

This term (sanctum) derives from the word sagmina. Sagmina are certain herbs which legates of the people of Rome customarily carry to ward off outrages ${ }^{20}$.

The wreath was woven not only from the green parts of grass and herbs, but entire plants were used for it, including roots and small clods of

${ }^{18}$ Liv. 1.24.6. Giovanni Turelli, Audi Iuppiter. Il Collegio dei Feziali nell'esperienza giuridica romana, Milano: Giuffrè 2011, p. 60.

${ }^{19}$ Liv. 1.24.4-6.

${ }^{20}$ Transl. A. Watson. 
earth sticking to them ${ }^{21}$. Romans believed that earth's soil contains a vital force, which would protect the fetiales remaining on foreign territory ${ }^{22}$. It is also possible that the intertwined roots symbolized the ties between the sides agreeing to the terms of the treaty $(\text { foedus })^{23}$. The herbs and grasses were picked on the Capitol, a hill which was considered to be sacred and was probably the seat of the fetiales ${ }^{24}$.

Immunity of an ambassador was perceived by the ancient people as an attribute of a sanctified person. The Romans had cherished this conviction since ancient times and it also existed at the time of creating Justinian's codification of the Roman law ${ }^{25}$. Envoys as sanctified persons are described for instance by Quintilian, who claims: let an envoy be sancrosanct (legatus sacrosanctus sit) ${ }^{26}$. The term sacrosanctus denoted an inviolable person, protected by religious and sacral sanctions ${ }^{27}$; a person who had received their status as a result of conducting appropriate ceremonies ${ }^{28}$. Additionally, it

${ }^{21}$ Fest. 242.34-426.5. See also: Plin. nat. hist. 22.5; 25.105. Jörg Rüpke, Domi militiae. Die religiöse Konstruktion des Krieges in Rom, Stuttgart: Franz Steiner Verlag 1990, 103.

${ }^{22}$ Kurt Latte, Römische Religionsgeschichte, München: Beck 1960, 121.

23 Thomas Wiedemann, “The Fetiales: A Reconsideration”, The Classical Quarterly 36 (1986), 485.

${ }^{24}$ Robert M. Ogilvie, A Commentary on Livy. Books I-V, Oxford: Oxford University Press, 110. The use of herbs was also connected with other activities performed on behalf of the state. For instance, grass was also used for decorating war altars devoted to Mars. An award in the form of a wreath made of grass was one of the greatest honours that could be bestowed upon a Roman citizen. Only a person who had prevailed over an enemy of Rome could be crowned with a wreath of grass. Mieczysław S. Popławski, Bellum Romanum. Sakralność wojny i prawa rzymskiego, Lublin: Wydawnictwo KUL 2011, 26-28.

${ }^{25}$ D. 50.16 .234 .

${ }^{26}$ Quint. decl. min. 366.2.

${ }^{27}$ John D. Grainger, Great Power Diplomacy in the Hellenistic World, London: Routledge 2017, 70.

28 The status of sacrosanctus could also result from the very nature of the phenomenon. Cic. pro Balb. 14.33. On the subject of the tribune of the people, Livy says the following: Expounders of the law deny that any one is sacrosanct by virtue of this statute, but maintain that the man who has injured any of these officials is solemnly forfeited to Jupiter $[. .$.$] whereas the tribunes are sacrosanct in consequence of the ancient oath taken$ by the plebs, when they first created this magistracy (Liv.3.55.8-10: Hac lege iuris interpretes negant quemquam sacrosanctum esse, sed eum qui eorum cui nocuerit Iovi sacrum sanciri [...] tribunos vetere iure iurando plebis, cum primum eam potestatem creavit, sacrosanctos esse). 
was believed that envoys stand for the whole nation of which they are representatives, hence a potential violation of their immunity would mean harm directed at the whole society ${ }^{29}$.

Apart from providing a description of the procedure for electing envoys, ancient sources also give an account of the way foreign envoys were received. The envoys' first duty was to inform the praetor or the city quaestor at the temple of Saturn about their arrival ${ }^{30}$. Next, the foreign emissaries informed the Roman senate ${ }^{31}$, and until the moment they were granted permission from the patres, they had to wait in a specially designated place ${ }^{32}$. They would be led in front of the senate by a consul or praetor during an official ceremony ${ }^{33}$. If the ambassadress had not sought an audience with the senate, there was no possibility that they would receive an answer on behalf of the Roman state ${ }^{34}$. However, the sources do not indicate that a lack of report from Roman officials on the purpose of an ambassadorial visit, and, what follows, no possibility for making a declaration of intent by the sides, had any detrimental effect on the envoys' status. Hence, they were still protected by immunity.

Both Livy and Valerius Maximus had no doubt that the abused Carthaginians arrived in Rome on a diplomatic mission. The incident of violating the envoys' bodily integrity could disturb the relative peace and already difficult relations between the states. Its consequences reached further that mere disturbance of public order. Carthage could demand that the perpetrators be delivered to them and in the case of failing to comply with their wish they had the right to declare war.

With reference to other magistrates the cover of immunity did not apply as, according to the historian, a potential capture of an aedile was a forbidden act under the statute, and not because of natural law.

${ }^{29}$ Cf. Liv. 1.24.

30 Theodor Mommsen, Römisches Staatsrecht, vol. 3.2, Basel: B. Schwabe 1887 (reprint Cambridge: Cambridge University Press 2009), 1148-1158. In the case of delegates sent by hostile peoples, with whom the Romans were in the state of war, it was necessary to have permission from high commanders of the Roman army to send emissaries. Liv. 37.49.

${ }^{31}$ Pol. 6.13.5-6. In special cases, permission was granted by officials, for instance the consul (Sail. lug. 104) or dictator (Liv. 30.40).

${ }^{32}$ Liv. 29.16.

${ }^{33}$ Liv. 42.6; Pol. 6.12.

${ }^{34}$ Liv. 42.26. Coleman Phillipson, The International Law, vol. 1, 317. 


\section{THE GROUNDS OF RESPONSIBILITY FOR ABUSING FOREIGN EMISSARIES}

A Roman citizen guilty of abusing a foreign ambassador had to be prepared to face numerous consequences. An act like that carried with itself not only consequences on the grounds of the ius gentium, but it also breached sacral norms.

An abuse of an ambassador equalled a sacrilege (sacrilegium). The offender acquired the status of a godless (impious) and impure person, and as such he was a threat to the community he belonged to and was a burden by his own very existence. Moreover, already at the moment of committing the abuse, the perpetrator brought upon himself the wrath of the gods offended by his actions. An individual's guilt could not be removed by an atoning sacrifice, but a ceremony of cleansing could be performed in order to remove the guilt from the whole community. Execration (exsacratio) of the perpetrator deprived him of his homeland, of the protection from domestic and state deities and excluded him from the protection by the $\mathrm{law}^{35}$. One could deprive an outlaw of his life, without facing any consequences. Depriving an outlaw of his homeland consisted in withdrawing his citizenship and all the associated privileges, thus equalling a civil death. Execration was not however perceived as a punishment, but more like a state in which a given person found himself $f^{36}$. It was believed that "god's vengeance" would reach the perpetrator at the right moment, thus claiming the offender's life.

As a result of his actions, the wrongdoer ousted himself from the framework of human law and entered the jurisdiction of gods' law ${ }^{37}$. It was an equivalent of the noxae datio on the grounds of sacral law. Noxal liability consisted in surrendering a wrongdoer to the injured party ${ }^{38}$. The

${ }^{35}$ Liv. 1.24.4-6.

${ }^{36}$ Rudolf von Jhering, Gest des römischen Rechts auf den verschiedenen Stufen seiner Entwicklung, vol. 1, Leipzig: Breitkopf und Härtel 1873, 280.

${ }^{37}$ Max Kaser, Das altrömische Ius. Studien zur Rechtsvollstellung und Rechtsgeschichte der Römer, Göttingen: Vandenhoeck \& Ruprecht 1949, 47.

${ }^{38}$ Atonement was sought after on the basis of actio noxalis. In order to avoid having to hand over the perpetrator, his senior agnate or owner could pay compensation money or private penalty. Max Kaser, Das römische Privatrecht, vol. I, München: Beck, 133. 
deity responsible for observing the oath and obeying international treaties was Jupiter ${ }^{39}$, hence it might be assumed that the perpetrators of the abuse must have been dedicated to this $\operatorname{god}^{40}$. However, it is not known whether the harm caused to envoys of a different state would also result in offending Jupiter, or perhaps another deity venerated in their country of origin.

Ancient historians emphasized that a breach of immunity of a foreign emissary is contrary to the ius gentium, disturbing international order ${ }^{41}$. This is what was claimed for instance by Polybius, when he wrote about the order issued by Queen Teuta of Illyria. She was to allegedly order the murder of a Roman ambassador on his return way home ${ }^{42}$. Some Roman jurists qualified this act in a similar way. In his comments on the works of Publius Mucius Scaevola of the $1^{\text {st }}$ century BC, Sextus Pomponius indicated that: D. 50.7.18.1: Si quis legatum hostium pulsasset, contra ius gentium id commissum esse existimatur, quia sancti habentur legati. Et ideo si, cum legati apud nos essent gentis alicuius, bellum cum eis indictum sit, responsum est liberos eos manere: id enim iuri gentium convenit esse. If someone strikes an ambassador of the enemy, he is regarded as having acted against law of nations, because ambassadors are regarded as sacred. And likewise if, when the ambassadors of some people were with us and war was declared against it and the reply was given that they were free to remain; for this befits the law of nations ${ }^{43}$.

39 The Romans also believed that the right relations with other peoples are protected by unidentified deities of law, faithfulness and honesty. Georges Dumézil, Archaic Roman Religion, t. I, Baltimore: Johns Hopkins University Press 1996, 208.

${ }^{40}$ Specific actions considered as sacrilegious would bring upon the perpetrator the wrath of specific gods. According to the lex duodecim tabularum, if any one stole the harvest from the field under the cover of the night, he was punishable with death by hanging in veneration of Ceres. (Plin. nat. hist. 18.3.12). This regulation is considered to refer to an action which was held as sacratio. William Warde Fowler, "The Original Meaning of the Word Sacer", The Journal of Roman Studies 1 (1911), 61. A person violating the immunity of the tribune of the people under lex Valeria Horatia of 449 BC was to be devoted to Jupiter. Liv.3.55.6-7.

${ }^{41}$ Also acts in breach of international agreements were treated as contra ius gentium. Cf. Liv. 40.27.6.

${ }^{42}$ Pol. 2.8.12.

${ }^{43}$ Transl. A. Watson. 
The jurist wrote about the envoys of the enemy (legatum hostium) ${ }^{44}$, which is confirmed in the historians' accounts, that such emissaries should be guaranteed safety also in a situation when their country was in a state of war with the country to which they travelled. A breach of such a promise was treated as an act violating the regulations on the matter of international relations. This in turn necessitated the implementation of sanctions which were usually applied on the international scene. However, on the current case Pomponius says:

D. 50.7.18.2-3: Itaque eum, qui legatum pulsasset, Quintus Mucius dedi hostibus, quorum erant legati, solitus est respondere.

So Quintus Mucius was accustomed to reply that someone who struck an ambassador was surrendered to the enemy whose ambassador he was ${ }^{45}$.

According to Scaevola, the society which the perpetrator originated from could remove the burden of responsibility off themselves by surrendering the offender to the affected ambassador's people. If there was the state of peace between the two nations, the standard procedure included seeking compensation for the inflicted harm, and in case of refusal, the declaration of war. In the discussed situation such a solution was not possible due to the fact that the two sides had already been in the state of war, declared in the appropriate way. The only possibility for mitigating the conflict resulting from violating bodily integrity of the envoys was to hand over the perpetrators. The violation of the immunity was an offence against the deities patronizing over the envoys and hence the envoys' people could be genuinely interested in repairing the damages. After all, in the times of war, one was better off having the gods on one's side.

In this context, it is worth mentioning another fragment of the Digest concerning the abuse of envoys, orators and people accompanying them. This issue was covered in lex Iulia de vi publica, an act dating back to the times of Julius Caesar or Octavian Augustus. In his comments on the responsibility of people holding public offices, Ulpian pointed out that

${ }^{44}$ Referring to Scaevola, Pomponius points out that the enemies are those who declared war against the Romans, or vice versa. Cf. D. 50.16.118.

${ }^{4}$ Transl. A. Watson. 
D. 48.6.7 in fine: Item quod ad legatos oratores comitesve attinebit, si quis eorum pulsavve et sive iniuriam fecisse arguetur

Again, so far as relates to ambassadors, pleaders, or those who accompany them, anyone who is proved to have beaten or done them an injury ${ }^{46}$.

However, in the fragment coming from Ulpian's work there is no mention that such an act was contrary to the ius gentium as its committing gave rise to responsibility on the grounds of the law created at the turn of the republic and the principate ${ }^{47}$. It would imply that at least from the time of lex Iulia entering into force, violating the immunity of an ambassador was punishable on the grounds of internal, citizens' law ${ }^{48}$. The perpetrator of the abuse towards the accompanying persons (comites) was also held responsible. The regulations of Iulia de vi publica were created over 150 years after the events concerning the beating of the Carthaginian envoys. There can be found no information in any of the sources whether the given law was a confirmation of the regulations existing before that or whether the transfer of responsibility from the ius gentium onto the Roman law was a novum.

\section{VIOLATION OF THE ENVOYS' IMMUNITY}

In their accounts, both Titus Livius and Valerius Maximus, referring to the violation of the immunity of the envoys, use the term pulsare, denoting, amongst other things, beating, ill-treatment and any other type of assault. A corresponding verb appeared in the above-mentioned legal regu-

${ }^{46}$ Transl. A. Watson.

${ }^{47}$ On the correlation of the discussed fragments of the Digest see: Franciszek Longchamps de Berier, "Nietykalność posła w Rzymie okresu Pryncypatu”, Prawo kanoniczne 37 (1994), 165-174.

${ }^{48}$ A law which incorporated sacrilegium into the Roman system of crimes was the lex Iulia peculatus of the $1^{\text {st }}$ century BC. More on the subject: Antoni Dębiński, Sacrilegium w prawie rzymskim, Lublin: Wydawnictwo KUL 1995, 16. 
lations and opinions of the jurists at the time of the decline of the republic and included in the Justinian's Digest ${ }^{49}$.

As a matter of fact, juridical sources concentrate rather on describing such acts as beating or ill-treatment. However, in the historical sources one can find descriptions on the basis of which one can create a broad catalogue of acts fitting the category of violating physical integrity of envoys, which might provide a premise for waging a just war. An obvious reason was manslaughter, as in the case of the war with Veii, when on king's orders Roman envoys were murdered (legatos Romanos... iussu Tolumni interfecerunt $)^{50}$. An attempted murder was treated in the same way ${ }^{51}$. In his account, Livy also says the following:

Liv. 4.58.6-7: [...] Veiens bellum motum ob superbum responsum Veientis senatus, qui legatis repetentibus res, ni facesserent propere urbe finibusque, daturos quod Lars Tolumnius dedisset responderi iussit.

[..] war broke out with Veii on account of the insolent reply of the Veientine senate, who, when envoys demanded restitution of them, bade them be answered that unless they got quickly out from their city and their borders, they would give them what Lars Tolumnius had given the others ${ }^{52}$.

On the basis of the above fragment, it might be claimed that an arrogant or insulting statement and threats could also be treated as the iusta causa belli. However, it should be taken into account that it was not a sufficient, stand-alone premise. The insulted fetiales arrived to the Veientines in order to ask for the due compensation (res repetitio), which they demanded at the end of the truce period ${ }^{53}$. As a matter of fact, they did not receive any formal answer to their claim, but the verbal onslaught from the senate of Veii was in no way ambiguous. In this light, Cassius Dio's account of verbal insults addressed at Carthaginian envoys might indicate that such an act might provide a single premise for declaring a just war.

\footnotetext{
${ }^{49}$ D. 48.6.7; 50.7.18.

${ }^{50}$ Liv. 4.17.1.

${ }^{51}$ Pol. 2.8.12.

${ }^{52}$ Transl. LOEB.

${ }^{53}$ Liv. 4.58.1.
} 
In their accounts of the presently discussed case, the historians did not describe any circumstances which surrounded the incident. Of course, it might be speculated that it was political or social atmosphere that was to blame, yet it would nevertheless remain in the sphere of conjecture. However, both Titus Livius and Valerius Maximus wrote that the fate of Lucius Minucius Myrtilus and Lucius Manlius was decided by praetor Marcus Claudius, even though only Livy provided the detail the he held the function of the city praetor. Yet again, there is no information on the proceedings against the perpetrator.

In 188 BC, both consuls remained outside Rome ${ }^{54}$, so the official of the highest authority remained praetor urbanus, Marcus Claudius. He must have been the one who introduced the Carthaginian envoys in front of the senate. It was also the praetor who, after the assault on the envoys, dealt with the matter of the impulsive Romans. The historians did not elaborate on how it was proven that Myrtilus and Manlius ${ }^{55}$ were guilty. Neither is it clear why it was the urban praetor that had the authority to deal with that matter ${ }^{56}$. The sources do not provide an answer whether it was part of his regular duties, as an official responsible for protecting public order in Rome (custodia urbis), or whether he was acting on the orders of the senate or the people's assembly ${ }^{57}$.

In the analyzed fragments it was not described how it came about that Lucius Minucius Myrtilus and Lucius Manlius were extradited, so in order to recreate the whole situation it is necessary to resort to other examples of extradition. The details of the procedure are described by Livy in his account of delivering Postumius to the Samnites ${ }^{58}$. As a matter of

${ }^{54}$ Liv. 38.35.7-1. Thomas R.S. Broughton, The Magistrates of the Roman Republic, vol. I, New York: American Philological Association 1951, 365.

55 Thomas R.S. Broughton, "Mistreatment of Foreign Legates and the Fetial Priest: Three Roman Cases”, Phoenix 41 (1987), 57.

${ }^{56}$ Dionysius of Halicarnassus claimed that it was the duty of the fetiales to examine cases of crimes committed against ambassadors. However, he did not say whether the college of priests was competent to examine the cases with regard to only Roman ambassadors, or whether the fetiales participated in the proceedings against the violators of immunity of foreign emissaries. Dion. Hal. 2.72.

${ }^{57}$ Cf. D. 50.7.18.

${ }^{58}$ The events concerning the Roman defeat at the Caudine Forks raise several doubts. One of the them concerns the legal status of the statement made by consul Spurius Postumius Albinus and the lack of possibility to verify whether a peace treaty was agreed on (foedus) without 
fact, in that case the reason for extradition was different, however, the Roman devotion to formal ceremonies and official duties justifies a speculation that the extradition carried out by the fetiales would be in its essence similar. Postumius and his associates were undressed by the wall of the town of the Samnites and their hands were tied behind their backs. Then they entered into town and one of the fetiales, Aulus Cornelius Arvina, addressed the gathered Samnites:

Liv. 9.10.9: „Quandoque hisce homines iniussu populi Romani Quiritium foedus ictum iri spoponderunt atque ob eam rem noxam nocuerunt, ob eam rem quo populus Romanus scelere impio sit solutus hosce homines vobis dedo".

Whereas these men, unbidden by the Roman People of the Quirites, have guaranteed that a treaty should be ratified, and by so doing have committed an injury; to the end that the Roman People may be absolved of heinous guilt, I deliver up these men to you ${ }^{59}$.

The formula uttered by the fetial included an indication of the act committed by the perpetrator, together with a statement as to his guilt. Next, Arvina proceeded with the delivery of the wrongdoer, emphasizing that in that way the Romans were cleansing themselves of the responsibility for that ungodly (impious) and inhumane deed. The term noxam nocere denoted the caused damage. It was in use in the legal language of the Romans already at the time of the lex duodecim tabularum, where it referred to the damage caused by a slave $e^{60}$.

The delivery of the perpetrator had a twofold purpose. The first one concerned the reparation of the damage caused to the Carthaginians, who,

the necessary enforcement of the senate and the assembly of the people, or whether the consul merely made a promise of peace (sponsio), giving his personal guarantee as to its implementation. Edward T. Salmon, "Pax Caudina", The Journal of Roman Studies 19 (1929), 12-18; Michael H. Crawford, "Foedus and Sponsio", Papers of the British School at Rome 41 (1973), 1-7; Michael Aston, "A Legal Interpretation of Livy's Caudine Sponsio: Using Roman Law to Test the Validity of Livy's Caudine Forks Narrative”, Past Imperfect 8 (1999-2000), 5-32.

59 Transl. LOEB.

${ }^{60}$ Tab. 12.2a. For further comments on the comparison between extradition and noxal liability under the ius civile see: Alan Watson, International Law in Archaic Rome, Baltimore-London: The Johns Hopkins University Press 1993, 39-41. 
deprived of the possibility to seek compensation from the Roman state, had to be satisfied with the punishment imposed upon the violators of the ambassadorial immunity. However, exclusion from the community did not entail compensation for the damage caused to the gods overlooking the ambassadorial mission. In fact, it consisted in transferring the responsibility for that act from the entire community onto the individuals who were the real perpetrators of the abuse.

In the case under discussion, according to Cassius Dio, the Carthaginians did not cause any harm to the Romans delivered to them, and even sent them back home. This in turn raises additional questions with regard to the consequences of extradition on the grounds of the ius gentium, as well as the sacral law. Meeting the requirements concerning the deditio seems to be a sufficient action with a view to repairing the damage on the international ground. The wrongdoers were delivered to the injured party, but the latter missed on the possibility of punishing the abusers. Thus, the potential conflict which could have been triggered by the violent actions of the Romans ended before it even started.

On the other hand, the situation when the injured community did not accept the delivered culprits seems to be more problematic from the perspective of sacral norms. Exsacratio caused a loss of citizenship, a civil death. Did a return of the wrongdoer to his homeland mean that he regained his original status $^{61}$ ? Such a problem also appeared on the grounds of other forbidden acts. The perpetrators of crimes which entailed exsacratio were permanently expelled from the sphere of sacrum, which was a sphere that guaranteed protection and security ${ }^{62}$. A return to society, together with regaining one's own previous status would be contrary to

${ }^{61}$ Pomponius points out that the issue of regaining citizenship by an exiled person had raised concerns of the jurists at least since the times of Scaevola, and most probably also earlier. In order to illustrate the problem, he referred to the handing over of Hostilius Mancinus to the Numantines, who refused to accept him. Mancinus was to regain his former status under a special law, which granted him citizenship. Pomponius also claims that according to some jurists the very surrender (deditio) entails the same legal consequences as aquae et ignis interdictio. Cf. D. 50.7.18.

${ }^{62}$ An example of such a crime was parricidium. On the subject of execration of the perpetrator of the above-mentioned act see: Maciej Jońca, Parricidium w prawie rzymskim, Lublin: Wydawnictwo KUL 2008, 277-284. 
submitting the wrongdoer to god's justice. Renouncement of infliction of a punishment by the Carthaginians definitely absolved the Romans from their responsibility towards Carthage, but did it do the same regarding their gods? Cassius Dio does not say whether Lucius Minucius Myrtilus and Lucius Manlius regained their citizenship. However, if we assume that they were received back into their community, it should be considered whether sacrilegium was indeed committed in the case of causing bodily harm to envoys. If it was not, thus referring to a person who violated ambassadorial immunity as outcast would be only a mere insult.

\section{CONCLUSION}

Irrespective of the doubts which arise while analyzing the cases of violating ambassadorial immunity and the degree of responsibility entailed in such an act, it should be remembered that personal immunity of emissaries of other people existed and was abided by at the time of the Roman Republic. It provided the basis for creating the concept of ambassadorial immunity at the time of the principate and in later periods, which was emphasized by including appropriate regulations into Justinian's codification.

The basis for acknowledging the immunity of foreign envoys was the ius gentium, which is proven in the historical and juridical sources. Despite the fact that the regulations concerning ambassadorial immunity in force on the international level were connected to sacral norms, it cannot be unequivocally concluded that the violation of bodily integrity of foreign delegates entailed sacrilegium in the understanding of the Romans. Without a doubt, such an act was an insult to the god overlooking the envoys, yet, the source material makes it impossible to analyze this phenomenon in greater depth and compare it to other acts which were sacrilegious in the light of Roman customs and law. 


\section{THE ANCIENT SOURCES}

Cass. Dio. - Dio Cassius. Roman History. Edited and translated by Earnest Cary. Vol. II: Books 12-35. Loeb Classical Library 37. Cambridge MA: Harvard University Press 1914.

Cic. de off. - Marcus Tullius Cicero. De officiis. Recognovit A. Alzert. Leipzig: B.G. Teubner 1963.

CIL - Corpus Inscriptionum Latinarum, consilio et auctoritate Academiae Litterarum Regiae Borussiae editum. Vol. VI.1. Berolini: G. Reimerum 1876.

D. - Digesta Iustiniani. Edited by T. Mommsen, P. Krüger. Berlin: Weidmann. 1954; Translated by Alan Watson. Vol I-II. Philadelphia: University of Pennsylvania Press 1998.

Dion. Hal. - Dionysius of Halicarnassus. Roman Antiquities. Edited and translated by Earnest Cary. Vol I: Books 1-2. Loeb Classical Library 319. Cambridge MA: Harvard University Press 1937.

Fest. - Festus. De verborum significatu quae supersunt cum Pauli epitome. Edited by W.M. Lindsay., Leipzig: B.G. Teubner 1913.

Liv. - Livy. History of Rome. Edited and translated by B.O. Foster et al. Vol I-XI. Loeb Classical Library 313. Cambridge MA: Harvard University Press 1919-2017.

Plin. Nat. hist. - Pliny the Elder. Natural History. Edited and translated by W. H. S. Jones. Vol. VI-VII. Loeb Classical Library 392-393. Cambridge MA: Harvard University Press 1951-1956.

Pol. - Polybios. The Histories. Edited and translated by W.R. Paton. Vol. I-VI. Loeb Classical Library 128, 137-138, 159-161. Cambridge MA: Harvard University Press 1922-1927.

Quint. decl. min. - Quintilian. The Lesser Declamations. Edited and translated by D. R. Shackleton Bailey. vol. II. Loeb Classical Library 501. Cambridge MA: Harvard University Press 2006.

Tab. - Lex XII tabularum. [in:] Fontes iuris Romani anteiustiniani. Edited by S. Riccobono. vol. I. Florentiae: Barbèra 1941.

Val. Max. - Valerius Maximus. Memorable Doings and Sayings, Vol. II: Books 6-9. Edited and translated by D. R. Shackleton Bailey. Loeb Classical Library 493. Cambridge MA: Harvard University Press 2000.

Varr. de ling. lat. - Varro. On the Latin Language. Edited and translated by R.G. Kent. Vol. I: Books 5-7. Loeb Classical Library 333. Cambridge MA: Harvard University Press 1938. 


\section{REFERENCES}

Albert, Sigrid. 1980. Bellum iustum: die Theorie des „gerechten Krieges” und ihre Bedeutung für die auswärten Auseinandersetzungen Roms in republikanischer Zeit. Kallmünz: Lassleben.

Aston, Michael. 1999-2000. "A Legal Interpretation of Livy's Caudine Sponsio: Using Roman Law to Test the Validity of Livy's Caudine Forks Narrative", Past Imperfect 8: 5-32.

Baldus, Christian. 2004. "Vestigia pacis. The Roman Peace Treaty: Structure or Event?", in: Peace Treaties and International Law in European History. From the Late Middle Ages to World War One. ed. Randall Lesaffer, 103-146. Cambridge: Cambridge University Press.

Bederman, David J. 2001. International Law in Antiquity. Cambridge: Cambridge University Press.

Betting, Maurizio, Alberto Borghini. 1983 "La guerra e lo scambio: hostis, perduellis, inimicus", in: Linguistica e antropologia. Atti del XIV Congresso Internazionale, Lecce 23-25 maggio 1980. Roma: Bulzoni: 305-312.

Broughton, Thomas R.S. 1951. The Magistrates of the Roman Republic. vol. I. New York: American Philological Association.

Broughton, Thomas R.S. 1987. "Mistreatment of Foreign Legates and the Fetial Priest: Three Roman Cases", Phoenix 41: 50-62.

Crawford, Michael H. 1973. "Foedus and Sponsio". Papers of the British School at Rome 41: 1-7.

Dahlheim, Werner. 1968. Struktur und Entwicklung des römischen Völkerrechts im 3. und 2. Jh v. Chr. München: Beck.

Dębiński, Antoni. 1995. Sacrilegium w prawie rzymskim. Lublin: Wydawnictwo KUL.

Dumézil, Georges. 1996. Archaic Roman Religion. vol. 1, Baltimore: Johns Hopkins University Press.

Fusinato, Guido. 1884. Dei feziali e del diritto feziale. Contributo alla storia del diritto pubblico esterno di Roma, in: Reale Accademia dei Lincei. Memorie della Classe di scienze morali, storiche e filologiche, XIII, Roma: Salviucci.

Grainger, John D. 2017. Great Power Diplomacy in the Hellenistic World. London: Routledge.

Grotkamp, Nadine. 2009. Völkerrecht im Prinzipat. Möglichkeit und Verbreitung. Frankfurt am Main: Nomos. 
Hausmaninger, Herbert. 1961. "Bellum iustum und iusta causa belli im älteren römischen Recht”, Österreichische Zeitschrift für öffentliches Recht 11: 335-345.

Hoyos, Dexter. 2015. Mastering the West: Rome and Carthage at War. Oxford: Oxford University Press.

Jhering, Rudolf von. 1873. Gest des römischen Rechts auf den verschiedenen Stufen seiner Entwicklung, vol. 1, Leipzig: Breitkopf und Härtel.

Jońca, Maciej. 2008. Parricidium w prawie rzymskim. Lublin: Wydawnictwo KUL.

Kaser, Max. 1949. Das altrömische Ius. Studien zur Rechtsvollstellung und Rechtsgeschichte der Römer. Göttingen: Vandenhoeck \& Ruprecht.

Kaser, Max. 1971. Das römische Privatrecht, vol. 1, München: Beck.

Latte, Kurt. 1960. Römische Religionsgeschichte. München: Beck.

Longchamps de Berier, Franciszek. 1994. "Nietykalność posła w Rzymie okresu Pryncypatu”, Prawo kanoniczne 37: 165-174.

Loreto, Luigi. 2001. Il bellum iustum e i suoi equivoci: Cicerone ed una componente della rappresentazione romana del Völkerrecht antico. Naples: Jovene.

Mantovani, Mauro. 1990.Bellum iustum. Die Idee des gerechten Krieges in der römischen Kaiserzeit. New York: Peter Lang International Academic Publishers.

Mommsen, Theodor. 1887. Römisches Staatsrecht, vol. 3.2, Basel: B. Schwabe (reprint Cambridge: Cambridge University Press 2009).

Oakley, Stephen P. 2005. A Commentary on Livy, Books VI-X, t. III: Book IX. Oxford: Oxford University Press.

Ogilvie, Robert M. 1965. A Commentary on Livy. Books I-V. Oxford: Oxford University Press.

Phillipson, Coleman. 1911. The International Law and Custom of Ancient Greece and Rome, vol. 1-2, London: MacMillan.

Popławski, Mieczysław S. 2011. Bellum Romanum. Sakralność wojny i prawa rzymskiego. Lublin: Wydawnictwo KUL.

Rüpke, Jörg. 1990. Domi militiae. Die religiöse Konstruktion des Krieges in Rom, Stuttgart: Franz Steiner Verlag.

Salmon, Edward T. 1929. "Pax Caudina", The Journal of Roman Studies 19: 12-18.

Scheid, John. 2006. "Oral Tradition and Written Tradition in the Formation of Sacred Law in Rome”, [in:] Religion and Law in Classical and Christian Rome, ed. Clifford Audo, Jörg Rüpke, Stuttgart: Franz Steiner Verlag. 
Sini, Francesco. 1991. Bellum Nefandum. Virgilio e il problema del „diritto internazionale antico", Sassari: Libreria Dessì Editrice.

Sordi, Marta. 2002. "Bellum iustum ac pium", in: Guerra e diritto nel mondo greco e romano, ed. Marta Sordi, 3-11. Milano: Vita e Pensiero, Pubblicazioni dell'Universita Cattolica.

Warde Fowler, William. 1911. "The Original Meaning of the Word Sacer", The Journal of Roman Studies 1: 57-63.

Watson, Alan. 1993. International Law in Archaic Rome. Baltimore-London: The Johns Hopkins University Press.

Wiedemann, Thomas. 1986. "The Fetiales: A Reconsideration”, The Classical Quarterly 36: 478-490.

Yakobson, Alexander. 2009. „Public Opinion, Foreign Policy and 'Just War' in the Late Republic“. in: Diplomats and Diplomacy in the Roman World, ed. Claude Eilers. 45-72. Leiden: Bril.

Ziegler, Karl Heinz. 1972. „Das Völkerrecht der römischen Republik“, in: Aufstieg und Niedergang der römischen Welt. vol. $\mathrm{I}_{2}$ : Von den Anfängen Roms bis zum Ausgang der Republik, ed. Joseph Vogt. 68-114. Berlin-New York: De Gruyter. 